\title{
The Differences in Perceptions of Interprofessional Education Among Health Profession Students: The Indonesian Experience [Erratum]
}

\author{
Syahrizal D, Renaldi T, Dianti SW, et al. J Multidiscip
}

Healthc. 2020;13:403-410.

The authors have advised the affiliation list on page 403 is incorrect. The text "Nursing Leadership and Management Department" was missed from affiliation 4. The correct author list and affiliations are as follows.

\author{
Dedy Syahrizal ${ }^{1}$ \\ Teuku Renaldi ${ }^{2}$ \\ Sukma Wulan Dianti ${ }^{3}$ \\ Noraliyatun Jannah ${ }^{4}$ \\ R Rachmah ${ }^{4}$ \\ Sarah Firdausa ${ }^{5}$ \\ Azizah Vonna ${ }^{6}$
}

'Department of Biochemistry, Faculty of Medicine, Universitas Syiah Kuala, Banda Aceh, Aceh, Indonesia; ${ }^{2}$ Department of Public Health, Faculty of Medicine, Universitas Syiah Kuala, Banda Aceh, Aceh, Indonesia; ${ }^{3}$ Bachelor of Medicine Program, Faculty of Medicine, Universitas Syiah Kuala, Banda Aceh, Aceh, Indonesia; ${ }^{4}$ Nursing Leadership and Management Department, Faculty of Nursing, Universitas Syiah Kuala, Banda Aceh, Aceh, Indonesia; ${ }^{5}$ Department of Internal Medicine, Faculty of Medicine, Universitas Syiah Kuala, Banda Aceh, Aceh, Indonesia; ${ }^{6}$ Department of Pharmacy, Faculty of Mathematics and Natural Sciences, Universitas Syiah Kuala, Banda Aceh, Aceh, Indonesia

\section{Publish your work in this journal}

The Journal of Multidisciplinary Healthcare is an international, peerreviewed open-access journal that aims to represent and publish research in healthcare areas delivered by practitioners of different disciplines. This includes studies and reviews conducted by multidisciplinary teams as well as research which evaluates the results or conduct of such teams or healthcare processes in general. The journal covers a very wide range of areas and welcomes submissions from practitioners at all levels, from all over the world. The manuscript management system is completely online and includes a very quick and fair peer-review system. Visit http://www.dovepress.com/testimonials. php to read real quotes from published authors. 